\title{
ETHICS EDUCATION IN APPLIED SPORT PSYCHOLOGY
}

\author{
Ana V. Vesković ${ }^{1}$, Nikola M. Petrović ${ }^{2}$ \\ ${ }^{1}$ University of Belgrade, Faculty of Sport and Physical Education, Serbia \\ ${ }^{2}$ University of Belgrade, Faculty of Philosophy, Department of Psychology, Serbia
}

\begin{abstract}
In applied sport psychology psychologists are often required to provide their services outside of the framework of traditional clinical practice, which has its advantages and limitations. Practitioners often face specific dilemmas and cannot find guidelines in the ethics code. Education in the field of ethics has been empirically proven as a powerful factor in the prevention of ethics violations. This issue becomes more important as there has been a growing number of psychologists in this field in recent years. That is why the focus of this paper is describing the specificity of ethics in applied sport psychology. Based on the review of the relevant literature, three most common issues have been identified: setting boundaries, confidentiality and competence. In the second, lesser, empirical part of the paper, the results of a pilot study on ethical beliefs related to the behavior of sports psychologists are presented. Data were collected on a sample of students of psychology $(\mathrm{N}=92)$, some of which might become sport psychologists. Some of the behaviors that are necessary for effective practice but are atypical for traditional clinical practice (for example, the presence of psychologists in competitions) are seen as unethical by almost half of the respondents. Most of the respondents have similar beliefs regarding the disclosure of confidential information to trainers. Recommendations which refer to the need to develop specific training programs in applied sport psychology ethics are also presented.
\end{abstract}

Keywords: CLINICAL SPORT PSYCHOLOGY / ETHICAL DILEMMAS / BOUNDARIES / CONFIDENTIALITY / COMPETENCE

\section{INTRODUCTION}

Sport psychology is a relatively young discipline that left the broader frames of psychology, sport sciences and medicine during 1960s (Stapleton, Hanks, Hayes \& Parham, 2010). Two sub-disciplines differentiated themselves within sport psychology (Wylleman, Harwood, Elbe, \& Caluwé, 2009): academic sport psychology and applied sport psychology (ASP). Sport psychology intertwines with clinical psychology within ASP. Besides the practice of providing clinical services (e.g. work with athletes that have mood disorder and eating disorders), the interventions that are, by their nature, educational, also apply within ASP, including training of mental skills required for top sport achievements (skills of relaxation, setting of goals, imagination, and other), learning communication skills with co-players and trainer and many others (Stapleton, et al., 2010; Weinberg, \& Gould, 2011). In accordance with the specificities of ASP appear characteristic ethical questions and possible ethical dilemmas that the practitioners meet. Beside the ones characteristic for clinical psychology, they include the ones characteristic for sport psychology and sport culture in general (Brown, \& Cogan, 1994; Moore, 2003). ASP belongs to the interdisciplinary areas where ethical questions are extremely important (Petitpas, Brewer, Rivera, \& Van Raalte, 1994).

\section{ETHICAL CODE AND ETHICS EDUCATION}

With a view to regulating the practice of this applied discipline, various professional associations have developed ethical codes, establishing the rules of (un)desired behaviour and acting in certain situations. Thus, for example, the National Association for Sport and Physical Education published "Ethical 
standards in providing services of NASPE members". The Association for the Advancement of Applied Sport Psychology accepted, in principle, the guidelines of the Ethical Code published by the American Psychological Association. In our environment, ethics of psychologists has been regulated by the ethical code of the Serbian Association of Psychologists (DPS, 2000), within which the specificities of ethics of sport psychologists have not been explicitly provided. Often and unfortunately, sport psychologists meet various ethical dilemmas for which there are not prescribed clear rules of behaviour (Lavallee, Kremer, Moran, \& Williams, 2004; Weinberg, \& Gould, 2011). This is precisely why the education of students and experts in ethics represent the strongest weapon in fighting against the violation of ethical rules (Vasquez, 1992). Its basic goal is adoption of a certain way of thinking in meeting with ethical dilemmas in practice and their solving (Pack-Brown $\&$ Williams, 2003). The Association of Applied Sport Psychology (AASP) has prescribed minimal standards for obtaining the sport psychologist certificate. According to these standards, which are the only ones recognised by the American Olympic Committee, the post-graduate studies of sport psychology should also contain the ethics module (Wylleman, Harwood, Elbe, \& Caluwé, 2009). Adoption and respect of professional ethics is connected to the professional identity of the practitioners in this area (Haberl, \& Peterson, 2006). It is determined by education, training, and qualifications (Wylleman, \& Lavallee, 2004). Most practitioners are graduated students of psychology specialised in sport psychology through additional trainings. On the other hand, many modern educational programmes in sport sciences include counselling and trainings in clinical psychology. Their different professional identity leads to their not abiding by the same ethical code (Brown, \& Cogan, 1994). The ability of recognising and development of special sensitivity for ethical questions and possible ethical dilemmas is crucial for ethical behaviour that influences competency (Brown, \& Cogan, 1994).

The subject of this paper are ethical beliefs and behaviours of sport psychologists. The paper presents some ethical questions which are most frequently mentioned as characteristic for ASP in the literature by foreign authors (Brown, \& Cogan, 1994; Huang, \& Hung, 2008; Moore, 2003; Stapleton et al., 2010;): setting of boundaries, confidentiality and compe- tency. As sensitivity for these questions is considered to be crucial for the efficient sport psychologist practice, and there are no published papers with this topic in our environment, the first objective of the paper is their presentation. In the recent years, more and more our local psychologists have dealt with ASP, and only three out of seven accredited faculties of psychology have subjects that are related to some area of professional ethics (non-specific, for psychology in general). In addition, the courses regarding professional ethics are an exception, rather than a rule (Petrović, 2016). The research shows that the beliefs are important because the psychologists' behaviour is mostly in accordance with beliefs (Pope, Tabachnik, \& Keith-Spiegel, 1987; Rubin \& Dror, 1996) and because they can largely influence the psychologists to respect or violate professional ethics (Petrović, 2016). In our environment, in most cases, the practitioners of ASP are psychologists, often without an additional formal education and training. The second objective hereof is to present the results of the explorative research - a pilot study - in which we have examined the beliefs of psychology students (future psychologists) regarding behavioural ethics of sport psychologists.

\section{MOST COMMON ETHICAL QUESTIONS IN APPLIED SPORT PSYCHOLOGY}

Setting of boundaries. Clear boundaries are set within the counselling and psychotherapeutic relationship with a goal to define the roles of each side in the relationship and to protect clients' welfare (Speight, 2012). In the last two decades, the literature has considered that not every crossing of the boundaries represents their violation and is not necessarily detrimental to the client (Barnett, Lazarus, Vasquez, Moorehead-Slaughter, \& Johnson, 2007). Consultations held by sport psychologists can, by their nature, represent crossing of the boundaries (Moles, Petrie, \& Watkins, 2016). Actually, when sport psychologists consider appropriateness of their behaviour, they should see it through the prism of the sport environment (Speight, 2012). Besides performing their practice in traditional places, in consulting rooms within the private practice or the university, it is usual that the sport psychologist holds the consultations with athletes and trainers outside 
the classical psychotherapeutic setting, for example, in the room for preparations before the competition, in the locker room, during a trip (on the bus, plane), in the hotel (Andersen, Van Raatle, \& Brewer, 2001; Brown, \& Cogan, 1994; Etzel \& Watson 2007; Moore, 2003; Stapleton, et al., 2010; Haberl, \& Peterson, 2006). This particularly regards the psychologists that work with sport teams or within sport organisations (Moore, 2003). More often than not, the schedules of the athletes are already planned in advance and they keep the athlete occupied throughout the day, and it does not leave room for the sessions to last the usual 45-60 minutes, but there is time only for short interventions that are sometimes performed during meals (Stapleton, et al., 2010). Such practice enables the psychologist to help the athlete function as optimally as possible, in order to realise his/her personal goals and the goal of the team and/or sports organisation (Moore, 2003). Athletes can feel more at ease when the psychologist is with them and when they can have consultations when they need them (for example, right after the competition, or upon defeat). The next advantage of such manner of work is in existence of more possibilities for the psychologist to know better both the trainer and the athlete, as well as to see their reactions in the critical situations. It is clear that in the described environment the boundaries are less rigid than in clinical practice. In addition, ethical dilemmas may appear in those situations when there is more social interaction (APA, 2002). For example, the psychologist can be invited to attend the celebration after the team victory or the trainers can invite him/her to have a drink in the bar. How should the psychologist act if he/she gets in such situation? If he/she refuses to come, it might create a distance in the relationship (and closeness in the psychologist-athlete relationship is crucial). Usually it takes longer for the psychologist to develop a good working alliance and closeness with athletes and other officials (if he/she works within a certain sports organisation), and to still be respected and trustworthy person (Moore, 2003). On the other hand, one should not neglect the second possible scenario: athletes that have come to the psychologist to solve specific problems and that have built a good working alliance with the psychologist can seek help in the future after the initial treatment is over. If the psychologist accepts the invitation to such events, it is necessary to be always aware of his/her professional boundaries, to "beware" of close interactions, and to have superficial conversations. The literature mentions the experience of the psychologist that was often invited to attend such social events. He imposed himself in the role of driver in the situations when alcohol was consumed, which enabled him to be involved in the event, but also to keep a professional relationship and to preserve the boundaries (Brown, \& Cogan, 1994). Another characteristic situation that can be ethically questionable regards the venue of holding consultations with athletes during trips. Let us imagine a frequent situation when there is no available separate room for holding consultations in the hotel. Holding consultations with athletes in the hotel lobby can lead to violation of the confidentiality principle. Also, the psychologist can hold the consultations with individual athletes or a group of athletes in the hotel room (Moore, 2003) which may open a question of potential sexual intentions (some psychologists solve this situation by working with the door open). Finally, the psychologist does not have to avoid such situations at any cost, but represents him/herself in a professional manner in these situations, making his/her role and manner of his/ her involvement clear for everybody (Moore, 2003).

Confidentiality. A good relationship between a professional, whether he/she is a psychologist, psychotherapist, consultant, supervisor, sport psychologist, and a client (that can be an individual athlete, sports team, a trainer and other club officials, parents of the athlete) represents a key component for the successful outcome (Stapleton, et al., 2010). Trust makes a basis of this relationship. Even the slightest violation of the confidentiality principle can reflect negatively on their relationship. Most often the third party - parents of the athlete, the trainer or other club officials can direct the athlete to the psychologist and realise the first contact with him/ her. It is not rare that the third party presumes that he/she is automatically entitled to the information regarding the sensitive data on the treatment and progress (Moore 2003). The additional complication can develop if the third party finances the treatment. This is a frequent situation with the parents that are highly involved in the sports activity of their children. It might happen that the psychologist works in parallel with the athlete and his/her parents. It is extremely important to develop a special sensitivity for additional questions and for keeping confidentiali- 
ty. In such cases the confidentiality issues are much more complex and require a special caution and balancing. One of the most delicate issues is to what extent every family member counts on confidentiality within the family, which is especially emphasized if the family members come individually as well. The two-way errors are possible. If the psychologist gives plenty of information (without violating a confidentiality principle), it may look as if the confidentiality principle was violated. Contrary to that, if the psychologist offers too few information, it can create a suspicion regarding the process itself. In such situations, the psychologist will act best if he/she encourages the family members to exchange the information when they consider it appropriate. When there is a doubt of such possibility, the psychologist can ask each family member which part of the information would be appropriate for sharing with other family members.

When the sports psychologist works with professional sports organisations, he/she cannot assume the same confidentiality boundaries as when he/she works with an individual athlete (Gardner, 2001). In that process one should bear in mind the objectives of the athlete and the objectives of the sports organisation if it has hired the psychologist (in such case the organisation is a client as well). Trainers, club officials, even the media can consider themselves entitled to this privileged information. For example, let us imagine that the sports club (the third party in the relationship) hires the psychologist to evaluate the characteristics of the athletes' personalities and that the psychologist's task is to draft the reports to the sports club. It is necessary to inform the athletes thereof. That is why during the very first contact with the third party the psychologist should set clear boundaries of confidentiality of information in the relationship with the athlete (Moore, 2003). If, for example, the third party asks the psychologist for the information on the athlete, he/she should direct it to the athlete. As the relationship between the psychologist and the third party may influence the quality and duration of the psychologist-athlete relationship, a relationship of trust should be developed between them. One of the first steps is to encourage the third party to support the athlete's treatment which implies respecting of confidentiality. If the consultant is a psychologist, he or she might happen to work with the athlete on the issues that go beyond the sport progress, even with the ones in the field of clinical psy- chology (eating disorders, anxiety, depression, etc.). In some cases the trainer can actively participate in the treatment. In such case it is necessary to ask the athlete for the written consent on the possibilities of disclosure of the information (and to what extent it can be given to the third party). More often than not, the trainers informed on the confidentiality boundaries ask the consultant the questions regarding the athlete's progress. For example, if the athlete has made a progress, the trainer wants to know the topics of the psychologist's conversation with the athlete, most probably in order to know how to support the athlete in future situations. These situations are more frequent if the trainer and the psychologist know each other personally. Then the psychologist can ask the athlete what and how much information he/she can disclose to the trainer. This situation is awkward for all parties involved, and it can be prevented by setting the agreement in advance, and the consultant's communication with the third party should be planned in advance as well. The APA code envisages that the psychologist can give the information to the third party, but only such that directly regards the achieving of a certain objective (professional or scientific) and only to a certain person. Other information that is not directly connected to the goal of the treatment must not be disclosed (APA, 2002).

Holding consultations in public places, during the training or during the competition is another important aspect of the practice for which the psychologist should develop a special sensitivity (Huang, \& Hung, 2008). Athletes should pay attention to the people around them, but the psychologist has to converse carefully on the confidential information that other persons can overhear. Andersen et al. (2001) give two suggestions regarding such situations. One of them is that the psychologist and the athlete try to find a sound proof room, and the other is to schedule the consultation regarding the sensitive matters for another time.

Competency. Sport psychology is a specialised domain and it requires a specialised competency (Brown, \& Cogan, 1994). It is wrong to believe that competency for sport psychology can be acquired by developing a huge interest in sport psychology topics, by reading the literature, or that former athletes or trainers possess such competency. Psychologists can be competent for counselling or psychotherapy, but in order to become competent for sport psychol- 
ogy, it is necessary to acquire a specific knowledge from sport sciences, as well as to continuously improve themselves (Stapleton et al., 2010). It is also important to possess certain competencies within the sub-specialty. So, for example, practitioners notice significant differences in working with the athletes of different competitive ranking (Stapleton et al., 2010). It is equally important to take into account specific aspects when working with young athletes, with university athletes, within sports organisations or with professional and top athletes, as well as specificities of each sports branch. Upon the completed formal programmes which include sport psychology courses, with a view to protecting the client's welfare, it is important for the psychologist to go to supervision, that may vary from frequent to annual, to a supervisor - field expert and to a peer supervisor (Barney, Andersen, \& Riggs, 1996). The relevant literature (Brown, \& Cogan, 1994; Moore, 2003; Stapleton et al., 2010) shows a consensus that psychologists can cross the borders of their competency in two manners. One of them is that the psychologist is hired to work with the athlete with a view to improving the competition performance, and he/she discovers a psychopathological problem (e.g. eating disorder, mood disorder) during work. If he/she is not trained for application of the treatment of such problem, and if he/she fails to refer the athlete to the colleague that is a specialist in this field, he/she performs the practice outside his/her competency. The other reflects in that the psychologist builds a counselling/psychotherapeutic relationship with the athlete that wishes to improve his/her competition performance, without being competent for working on improvement of the sports performance - has not mastered the mental training for athletes. Also, the application od measuring instruments which the psychologist is not qualified for, represents crossing of the competency boundaries (Moore, 2003).

\section{BELIEFS OF PSYCHOLOGY STUDENTS REGARDING THE BEHAVIOURAL ETHICS OF SPORT PSYCHOLOGISTS}

\section{Sample and procedure}

Psychology students of the Faculty of Philosophy of the University of Belgrade took part in the research $(\mathrm{N}=92)$, out of which $75(81,52 \%)$ girls and
$17(18,48 \%)$ boys. The average age of the participants is 22,08 years $(\mathrm{SD}=1,59)$. A majority of students is on the third year of studies, $79(85,87 \%)$, and the rest is on the fourth year, $13(14,13 \%)$. The percentage of students that declined to participate in the research was insignificant $(10,6 \%)$ and non-systemic. The research was anonymous, and the questionnaires were applied via the platform SurveyMonkey.

\section{Instrument}

The questionnaire contains 9 items which describe hypothetical behaviours of sport psychologists, and the participants should estimate ethicality of these behaviours on the five-point Likert scale (from $1=$ undoubtedly unethical to $5=$ undoubtedly ethical), by indicating to what extent they agree that certain actions are not ethical. The statements in the items are in the third person, e.g. "Disclosing confidential data on the athlete to the trainer". The author's theoretical knowledge and practical experiences served as the sources used for determining the content of the test items.

\section{RESULTS}

Most items in the questionnaire describe complex ethical issues. The results obtained ( $\mathrm{f}$ and \%) are presented in Table 1. The psychologist's behaviours regarding accepting the invitations for going to the match, to the celebration, romantic or sexual involvement with the client, regard the principle of respecting boundaries. The results of this research show that two thirds of participants consider the romantic involvement with a former client undoubtedly unethical, or ethical in rare situations. Even bigger level of agreement exists (almost all participants) regarding the sexual involvement with a current client, which is strictly forbidden by the ethical code. This behaviour is estimated as undoubtedly unethical by the students. However, some $70 \%$ of the students think that attending the team celebration after the victory is undoubtedly unethical or ethical in rare situations. If one bears in mind that sport psychologists frequently hold their consultations in non-traditional places, including competitions, the concerning data is that almost half of the students (47\%) considers accepting the invitation to the competition to be unethical. Only less than $10 \%$ of the participants opine that such behaviour, characteristic for sport psychologists, is 
undoubtedly ethical. Interesting data were obtained regarding the confidentiality principle - disclosure of the data to the parents, trainer and owner of the club, as well as including testimonials of athletes regarding the psychologist's work as advertisement. More than a half of the participants think that including of testimonials of athletes regarding the psychologist's work in advertisements is undoubtedly unethical. Approximately one fifth of the participants think that disclosing the data on the underage client to their parents is undoubtedly unethical. A significantly higher percentage of them, close to $60 \%$, think that disclosing of the data to the team owner is undoubtedly unethical, and the biggest consensus (91\%) was achieved regarding the belief that disclosing of the data on the athlete to his/her trainer is undoubtedly unethical. No participant opted for the answer that disclosing of the data to the trainer is ethical in most situations or undoubtedly ethical. When it comes to competen$\mathrm{cy}$, a relatively high percentage of examined students (85\%) think that counselling related to the problem which the psychologist is not competent for falls under the category of unethical behaviour.

Table 1. Frequency and percentage of answers of the participants for each category of questions in the questionnaire

\begin{tabular}{|c|c|c|c|c|c|}
\hline Questionnaire items & $\begin{array}{c}\text { Undoubtedly } \\
\text { unethical } \\
\text { behaviour } \\
\text { f(\%) }\end{array}$ & $\begin{array}{c}\text { Ethical } \\
\text { behaviour } \\
\text { in rare } \\
\text { situations } \\
\mathbf{f}(\%)\end{array}$ & $\begin{array}{c}\text { Behaviour } \\
\text { that is } \\
\text { sometimes } \\
\text { ethical } \\
\text { f(\%) }\end{array}$ & $\begin{array}{c}\text { Ethical } \\
\text { behaviour } \\
\text { in most } \\
\text { situations } \\
\mathbf{f}(\%)\end{array}$ & $\begin{array}{c}\text { Undoubtedly } \\
\text { ethical } \\
\text { behaviour } \\
\text { f(\%) }\end{array}$ \\
\hline $\begin{array}{l}\text { Celebrating with the team in the bar after the } \\
\text { victory }\end{array}$ & $35(46,1)$ & $18(23,7)$ & $13(17,1)$ & $7(9,2)$ & $3(3,9)$ \\
\hline $\begin{array}{l}\text { Accepting the client's invitation to the match } \\
\text { or competition }\end{array}$ & $15(19,7)$ & $21(27,6)$ & $16(21,1)$ & $17(22,4)$ & $7(9,2)$ \\
\hline Romantic involvement with the former client & $38(50,0)$ & $14(18,4)$ & $14(18,4)$ & $4(5,3)$ & $6(7,9)$ \\
\hline Sexual involvement with the client & $74(97,4)$ & $1(1,3)$ & $1(1,3)$ & I & I \\
\hline $\begin{array}{l}\text { Including of athletes" "testimonials" of the } \\
\text { successful work of a sport psychologist in } \\
\text { advertisement }\end{array}$ & $39(51,3)$ & $26(34,2)$ & $7(9,2)$ & $4(5,3)$ & l \\
\hline $\begin{array}{l}\text { Disclosing confidential data on the underage } \\
\text { client to his/her parents }\end{array}$ & $16(21,1)$ & $33(43,4)$ & $15(19,7)$ & $8(10,5)$ & $4(5,3)$ \\
\hline $\begin{array}{l}\text { Disclosing confidential data on the athlete to } \\
\text { the trainer }\end{array}$ & $69(90,8)$ & $5(6,6)$ & $2(2,6)$ & l & l \\
\hline $\begin{array}{l}\text { Disclosing of the data on the progress in } \\
\text { working with the client to the team owner }\end{array}$ & $45(59,2)$ & $15(19,7)$ & $10(13,2)$ & $4(5,3)$ & $2(2,6)$ \\
\hline $\begin{array}{l}\text { Counselling the client regarding the problem } \\
\text { which the psychologist is not competent to } \\
\text { solve }\end{array}$ & $34(44,7)$ & $31(40,8)$ & $7(9,2)$ & $2(2,6)$ & $2(2,6)$ \\
\hline
\end{tabular}

\section{DISCUSSION}

For achieving professional objectives within ASP, it is important for the psychologists to integrate into the sports environment and to adapt their practice to the requirements of sport culture. Such environment requires the psychologist to be spontaneous, flexible and able to respond to the clients' changing needs. They meet ethical dilemmas atypical for the standard psychotherapeutic practice, that most frequently regard the questions of preserving the boundaries in the environment that is not considered traditional for the psychologist's practice, the questions of confidentiality and the questions of competency (Brown, 
\& Cogan, 1994; Moore, 2003). On the other hand, it goes without saying that psychologists should abide by the ethical code, and that they should acquire a specific ethical knowledge that influences the manner of their behaving with ethical challenges. The development of a specific sensitivity for ethical questions is especially important for the psychologists that work within sports organisations Gardner 2001). Bearing in mind that, in the recent years, there have been increasingly more psychologists engaged in this field in our environment, and that we do not have a formal ethical education in this area nor the Serbian Association of Psychologists' code emphasizes the specificities of ethics of sport psychologists, the first objective hereof has been to present characteristic ethical dilemmas and possible situations in which they may be generated. The second objective has been to examine empirically how the psychology students - future experts of which some may prefer working within ASP - estimate ethicality of the sport psychologists' behaviour in certain situations.

In the context of performing ASP, the boundaries are less rigid comparing with the classical psychotherapeutic practice (Andersen et al., 2001; Brown, \& Cogan, 1994; Etzel \& Watson 2007; Haberl, \& Peterson, 2006; Moore, 2003; Stapleton et al., 2010). Unlike numerous researches related to the boundaries in the psychotherapeutic and counselling relationship, there is almost no research dedicated to the same questions in the sport psychologist/athlete relationship with which we can compare the results of our research. Almost half the participants thinks that going of the psychologist to the sports competition is unethical, and even more of them, some $70 \%$, shares the opinion on attending social events by the psychologist. Our results are endorsed by the research of Petitpas et al. (1994), according to which more than $40 \%$ of the participants - ASP practitioners registered with the AAASP in USA considers attending social events to be undoubtedly unethical, and slightly less than $25 \%$ considers it to be ethical in rare situations. However, the results of the research of Moles et al. (2016) do not endorse the results of our research. According to the results of that research, over $90 \%$ of the participants thinks that attending competitions and special events and small social gatherings belong to the category of behaviours that are mostly professional. When we compare the differences in the results obtained, we should bear in mind that the participants in our research were students of final years of stud- ies, and that they have not attended specific courses in sport psychology ethics, while in the research of Moles et al. the participants were certified ASP practitioners (including psychologists or experts in sports sciences). Actually, these behaviours can be necessary for efficient and professional performing of sport psychologists' practice (Haberl, \& Peterson, 2006) and it is obvious that the beliefs of American psychologists have changed over time. The participants in this research think that sexual involvement with the former client is undoubtedly unethical, which corresponds to the results of Petitpas et al. (1994). These researchers reported that more than $92.7 \%$ participants does not consider this behaviour to be ethical in any situation.

Confidentiality in the psychologist-athlete relationship is deemed a foundation stone of the efficient practice (Moore, 2003). Usually it takes longer for the psychologist to realise a good working alliance, closeness and trust relationship with the clients. This is precisely why it is recommended to the psychologist to accept to perform a part of his/her practice "in the field", when the athletes need it most. The literature emphasises that attending various social events does not have to be detrimental to the client's progress or to their relationship. In such circumstances it is essential that the psychologist is aware of his/ her behaviour at all times and to preserve professional boundaries in the relationship (Brown, \& Cogan, 1994). In fulfilling the needs of the team, as of the individual athletes in the team, the psychologists faces the requirements related to respecting the confidentiality principle (Stapleton et al., 2010). If the psychologist works with underage athletes whose parents are interested in the details of the progress and course of the treatment, the psychologist has to protect the entrusted information. One of the key steps in this process is for the psychologist to support the third party in the relationship (parent, trainer, club official) to respect the confidentiality principle and to inform them thereof during the very first contact (Moore 2003). Somewhat unexpected results were obtained in our research. Namely, there is a relatively high consensus of the participants regarding that disclosing the confidential data on the athlete to the third party is an unethical behaviour. The answers obtained are in accordance with the code which envisages that the psychologist may disclose to the third party only the information regarding the achieving of a certain professional goal (APA, 2002; DPS, 2000). However, while almost $80 \%$ of the participants estimates that 
disclosing the data to the athletes' parents is sometimes ethical and around $40 \%$ believes the same about disclosing information to the team owner, it represents a paradox that less than $10 \%$ of respondents thinks that disclosing the data to the trainer (who is the only one in the role of instructor, mentor, demonstrator, professional adviser) falls under the category of ethical behaviour in certain situations. In the lack of empirical data for the interpretation of the results obtained, we can express the assumption that precisely the specific role and responsibility of the trainer is something that causes our participants to doubt and fear the possible unintentional abuse of the data.

Working with the problems which the psychologist is not qualified for is opposite to the principle of competency. Achieving of competency within ASP requires possession of specialised knowledge and skills (Brown, \& Cogan, 1994) that represent an integration of various fields of psychology, sport medicine and sport sciences. For the efficient practice, it is necessary that the psychologist knows the specificities of each sports branch, level of competition and characteristics of each athlete. The variety of questions and issues which the practitioners meet has led to the development of certain sub-specialties (Stapleton, Hanks, Hayes \& Parham, 2010). Upon the completion of the formal education, a continuous improvement and various form of supervision can significantly contribute to the further development and maintaining the competency (Barney et al., 1996). In our research, some $85 \%$ of the participants estimated that counselling the clients for the problem which the psychologist is not competent for falls under the categories of unethical behaviour (undoubtedly and in rare situations). The corresponding research findings were obtained in the research of Petitpas et al. (1994) according to which some $87 \%$ of the participants considered working with the problems for which the psychologist does not have a formal training to be unethical behaviour, and at the same time some $73 \%$ of the participants considered counselling the athlete without the training in the area of counselling and/or psychotherapy to be unethical (or in rare situations ethical) behaviour.

In practice, sports coaches, whether they are more or less actively involved with a sports psychologist, may influence the frequency of ethical dilemmas by engaging them and with their demands to athletes and psychologists. Viewed from that angle, it would be important to examine the views of physical education and sport students about how much the behaviour of sports psychologists is ethical or unethical. The obtained results would be the starting point for creating ethical education programs for future sports coaches (and not just psychologists), and the results of this research would gain more ecological validity.

\section{CONCLUSION}

For professional and efficient performing of the complex ASP practice, it is necessary that the psychologist fully understands his/her professional role and that he/she assimilates his/her practice in the sport culture in accordance with specific requirements and needs of a unique clientele. In parallel with the ever growing interest and the increasing popularity of this interdisciplinary field, appear numerous questions related to the manner of providing the best services possible, respecting ethics. One of the newest is working with athletes via internet (e.g. through Skype), because they often travel abroad and psychologists can't always travel with them. As in our environment ASP is still gaining its reputation, it may happen that the inefficient practice discredits not only the psychologist, but the profession as well. Besides, this first empirical data on ethical beliefs regarding behaviours of sport psychologists indicates the need for development of specific training programmes in ASP ethics in our environment. The starting point and the role model for developing such programmes can be training programmes and experiences of the sport psychologists from the countries in which such programmes have already been developed.

Notes: The study was supported by the Ministry of Education, Science and Technological Development of Republic of Serbia (III47015; No 47008). 


\section{REFERENCES}

1. Anderesen, M. B., Van Raatle, J. L., \& Brewer, B. W. (2001). Sport Psychology Service Delivery: Staying Ethical While Keeping Loose. Professional Psychology: Research and Practice, 32, 12-18.

2. American Psychological Association. (2002). Ethical principles of psychologists and code of conduct. American Psychologist, 57, 1060-1073.

3. Barnett, J. E., Lazarus, A. A., Vasquez, M. J. T., Moorehead-Slaughter, O., \& Johnson, W. B. (2007). Boundary issues and multiple relationships: Fantasy and reality. Professional Psychology: Research and Practice, 38, 401-410.

4. Barney, S. T., Andersen, M. B., \& Riggs, C. A. (1996). Supervision in sport psychology: Some recommendations for practicum training. Journal of applied sport psychology, 8, 200-217.

5. Brown, J. L., \& Cogan, K. D. (2006). Ethical clinical practice and sport psychology: When two worlds collide. Ethics \& behavior, 16, 15-23.

6. Društvo psihologa Srbije (2000). Kodeks etike psihologa Srbije. [Code of Ethics of Psychologists of Serbia, In Serbian] Beograd: Društvo psihologa Srbije.

7. Etzel, E., \& Watson, J. (2007) Ethical challenges for psychological consultations in intercollegiate athletics. Journal of Clinical Sport Psychology, 1, 304-317.

8. Gardner, F. L. (2001). Applied sport psychology in professional sports: The team psychologist. Professional Psychology: Research and Practice, 32, 34-39.

9. Lavallee, D., Kremer, J., Moran, A.P., \& Williams, M. (2004). Sport Psychology: Contemporary Themes. New York: Palgrave Macmmillan.

10. Haberl, P., \& Peterson, K. (2006). Olympic-size ethical dilemas: Issues and challenges for sport psychology consultants on the road and Olympic Games. Ethics \& Behavior, 16, 25-40.

11. Huang, C. J., \& Hung, T. M. (2008). Ethical issues in sport psychology services: Dual relationships, confidentiality, and competence boundaries. Bulletin of Sport and Exercise Psychology of Taiwan, 13, 53-69.

12. Moles, T. A., Petrie, T. A., \& Watkins, C. E. (2016). Sex and Sport: Attractions and Boundary Crossings Between Sport Psychology Consultants and Their Client-Athletes. Professional Psychology: Research and Practice, 47, 93-101.

13. Moore, Z.E. (2003). Ethical Dilemmas in Sport
Psychology: Discussion and Recommendations for Practice. Professional Psychology: Research and Practice, 34, 601-610.

14. Petitpas, A. J., Brewer, B. W., Rivera, P. M., \& Van Raalte, J. L. (1994). Ethical beliefs and behaviors in applied sport psychology: The AAASP ethics survey. Journal of Applied Sport Psychology, 6, 135-151.

15. Pack-Brown, S. P., \& Williams, C. B. (2003). Ethics in a multicultural context. London: Sage Publications, Inc.

16. Petrović, M.N. (2016). Efekat etičke pozicije i edukacije na etička uverenja psihologa koji se bave psihoterapijom u Srbiji. Primenjena psihologija, 9, 261-272.

17. Pope, K. S., Tabachnick, B. G., \& Keith-Spiegel, P. (1987). Ethics of practice: The beliefs and behaviours of psychologists as therapists. American Psychologist, 42, 993-1006.

18. Rubin, S., \& Dror, O. (1996). Professional ethics of psychologists and physicians: Mortality, confidentiality, and sexuality in Israel. Ethics and Behavior, $6,213-238$.

19. Speight, S. (2012). An exploration of boundaries and solidarity in counseling relationships. The Counseling Psychologist, 40, 133-157.

20. Stapleton, A., Hanks, D., Hayes, K., \& Parham, W. (2010). Ethical dilemmas in sport psychology: A dialogue on the unique aspects impacting practice. Professional Psychology: Research and Practice, 41, 143-152.

21. Wylleman, P., Harwood, C. G., Elbe, A.-M., \& de Caluwé, D. (2009). A perspective on education and professional development in applied sport psychology. Psychology of Sport and Exercise, 10, 435-446.

22. Weinberg, R., \& Gould, D. (2011). Foundations of Sport and Exercise Psychology (5h Ed.). Champaign, Illinois: Human Kinetics. 


\section{ETHISCHE BILDUNG IN ANGEWANDTER SPORTPSYCHOLOGIE}

\section{Zusammenfassung}

In der angewandten Sportpsychologie wird von Psychologen oft erwartet, ihre Arbeit außerhalb des Rahmnes der traditionellen klinischen Praxis zu machen, was Vorteile, aber auch Begrenzungen hat. Praktiker sind oft mit spezifischen Dilemmas konfrontiert und können nicht alle Antworten im Ethikkodex finden. Empirisch wurde dokumentiert, dass ethische Bildung ein wichtiges Instrument im Kampf gegen den Bruch von ethischen Prinzipien darstellt. Sie bekommt an Kraft, unter anderem auch wegen der Tatsache, dass in den letzten Jahren die Anzahl von Psychologen in diesem Bereich angestiegen ist. Aus diesem Grunde befindet sich der Schwerpunkt dieser Arbeit auf dem ersten Ziel - der Beschreibung des Spezifikums der Ethik in der angewandten Sportpsychologie. Auf Grund einer Revision von relevanter Literatur wurden die drei häufigsten Fragen ausgesondert: die Festlegung von Grenzen, Vetraulichkeit und Kompetenz. Im zweiten, kleineren empirischen Teil wurden Ergebnisse einer Pilotstudie über ethische Überzeugungen in Bezug auf das Verhalten von Sportpsychologen vorgestellt. Die Informationen wurden an einem Muster von Psychologiestudenten (N=92) gesichert, von denen manche vielleicht den Beruf des Sportpsychologen aussuchen werden. Manche der Verhaltensweisen, die für effiziente praktische Arbeit unumgänglich, aber untypisch für die traditionelle klinische Praxis sind (z.B. Anwesenheit eines Psychologen bei einem Wettbewerb) wurden fast von der Hälfte der Prüflinge als unethisch eingeschätzt. Die größte Übereinstimmung der Prüflinge wurde bei der Frage über die Enthüllung von vetraulichen Informationen dem Trainer gegenüber erzielt. Auf Grund dieser Arbeit wurde eine Empfehlung formuliert, die sich auf das Bedürfnis nach Entwicklung von spezifischen Trainingsprogramms für Ethik in angewandter Sportpsychologie bezieht.

Schlüsselwörter: KLINISCHE SPORTPSYCHOLOGIE / ETHISCHE DILEMMAS / GRENZEN / VETRAULICHKEIT / KOMPETENZ

Received: 09.11.2017

Accepted: 05.12.2017 


\title{
ЕТИЧКО ОБРАЗОВАЊЕ У ПРИМЕЊЕНОЈ ПСИХОЛОГИЈИ СПОРТА
}

\author{
Ана В. Весковић ${ }^{1}$, Никола М. Петровић ${ }^{2}$ \\ Универзитет у Београду, Факултет спорта и физичког васпитања, Србија \\ Универзитет у Београду, Философски факултет, Одсек за психологију, Србија
}

\begin{abstract}
Сажетак:
У примењеној психологији спорта (ППС), од психолога се често захтева, да своје услуге пружају изван оквира традиционалне клиничке праксе, што има и предности и ограничења. Практичари се често сусрећу са специфичним дилемама, а не могу наћи све одговоре у кодексу етике. Емпиријски је документовано да је едукација из етике значајно оружје у борби против кршења етичких начела. Она добија на снази, уважавајући чињеницу да је последњих година порастао број психолога у овој области. Управо зато је тежиште овога рада на првом циљу - описивању специфичности етике у ППС. На основу прегледа релевантне литературе, издвојена су три најчешћа питања: постављање граница, поверљивост и компетентност. У другом, мањем, емпиријском делу приказани су резултати пилот студије о етичким уверењима у вези са понашањем спортских психолога. Подаци су прикупљени на узорку студената психологије (N=92), од којих ће неки можда постати спортски психолози. Нека од понашања, која су неопходна за ефикасно обављање праксе, а атипична су за традиционалну клиничку праксу (на пример, присуствовање психолога такмичењима), готово половина испитаника проценила је као неетична. Највећа сагласност испитаника постигнута када је питању откривање поверљивих података тренеру. На основу овог рада формулисана је препорука која се односи на потребу развоја специфичних програма тренинга из етике у ППС.
\end{abstract}

КљУчне речи: КЛИНИЧКА СПОРТСКА ПСИХОЛОГИЈА / ЕТИЧКЕ ДИЛЕМЕ / ГРАНИЦЕ / ПОВЕРЉИBOCT / КОМПЕТЕНТНОСТ

\section{УВОД}

Психологија спорта је релативно млада дисциплина која се 60-их година прошлог века издвојила из ширих оквира психологије, наука о спорту и медицине (Stapleton, Hanks, Hayes \& Parham, 2010). У оквиру психологије спорта издвојиле су се две субдисциплине (Wylleman, Harwood, Elbe, \& Caluwé, 2009): академска психологија спорта и примењена психологија спорта (ППС). У оквиру ППС укрштају се психологија спорта и клиничка психологија. Поред праксе пружања клиничких услуга (нпр. рад са спортистима који имају поремећај расположења или поремећаје исхране), у оквиру ППС примењују се и интервенције које су по природи едукативне, а укључују тренинг менталних вештина потребних за врхунска спортска достигнућа (вештине релаксације, постављања циљева, имагинацију, и др.), учење вештинама комуникације са саиграчима и тренером и многе друге (Stapleton, et al., 2010; Weinberg, \& Gould, 2011). У складу са специфичностима ППС појављују се карактеристична етичка питања и могуће етичке дилеме са којима се практичари сусрећу. Поред оних битних за клиничку психологију, она укључују и оне карактеристичне за психологију спорта и за спортску културу уопште (Brown, \& Cogan, 1994; Moore, 2003). ППС припада интердисциплинарним областима у којима су етичка питања изузетно значајна (Petitpas, Brewer, Rivera, \& Van Raalte, 1994). 


\section{ЕТИЧКИ КОДЕКС И ОБРАЗОВАЫЕ ИЗ ЕТИКЕ}

У циљу регулисања праксе ове примењене дисциплине, различита струковна удружења психолога развила су и примењују етичке кодексе у којима су утврђена правила (не)пожељног понашања и поступања у одређеним ситуацијама. Тако је на пример, Национално удружење за спорт и телесно образовање објавило „Етичке стандарде у пружању услуга НАСПА чланова“. Удружење за унапређивање примењене психологије у начелу је прихватило смернице Етичког кодекса који је објавила Америчка психолошка асоцијација. У нашој средини, етика психолога је регулисана етичким кодексом Друштва психолога Србије (ДПС, 2000), у оквиру кога нису експлициране специфичности етике спортских психолога. Не ретко и нажалост, спортски психолози се сусрећу са етичким дилемама за које нису прописана јасна правила понашања (Lavallee, Kremer, Moran, \& Williams, 2004; Weinberg, \& Gould, 2011). Управо зато едукација студента и стручњака из етике, представља најјаче оружје у борби против кршења етичких правила (Vasquez, 1992). Њен основни циљ је усвајање одређеног начина размишљања у сусретању са етичким дилемама у пракси и њиховог решавања (Pack-Brown \& Williams, 2003). Удружење примењене психологије спорта (ААСП) прописало је минималне стандарде за добијање сертификата спортских психолога. Према овим стандардима, који су једино признати од стране Америчког олимпијског комитета, последипломске студије психологије спорта треба са садрже и модул из етике (Wylleman, Harwood, Elbe, \& Caluwé, 2009). Усвајање и поштовање професионалне етике у вези је са професионалним идентитетом практичара из ове области (Haberl, \& Peterson, 2006). Он је је одређен образовањем, обуком (тренингом) и квалификацијама (Wylleman, \& Lavallee, 2004). Већина практичара су дипломирани студенти психологије који су се кроз додатне тренинге специјализовали за психологију спорта. Са друге стране, многи савремени програми едукације из наука о спорту укључују саветовање и тренинге из клиничке психологије. Њихов различит професионални идентитет води томе да се они не држе идентичног етичког кодекca (Brown, \& Cogan, 1994). За етичко понашање, које утиче на компетентност, од суштинског зна- чаја је способност препознавања и развоја посебне осетљивости за етичка питања и могуће етичке дилеме (Brown, \& Cogan, 1994).

Предмет овог рада су етичка уверења и понашања спортских психолога. У раду су приказана нека етичка питања карактеристична за ППС која се у литератури страних аутора (Brown, \& Cogan, 1994; Huang, \& Hung, 2008; Moore, 2003; Stapleton et al., 2010) најчешће наводе као карактеристична за ППС: постављање граница, поверљивост и компетентност. Будући да се осетљивост за ова питања сматра кључном за ефикасну праксу спортског психолога, те да у нашој средини нема публикованих радова на ову тему, први циљ рада је њихово представљање. Последњих година, све већи број психолога у нашој средини, бави се ППС, а на само три од седам акредитованих факултета психологије имају предмете који се тичу неке области професионалне етике (неспецифично, за психологију уопште). Додатно, курсеви који се тичу професионалне етике изузетак су, а не правило (Петровић, 2016). Истраживања показују да су уверења важна зато што је понашање психолога углавном у складу са уверењима (Роре, Tabachnik, \& Keith-Spiegel, 1987; Rubin \& Dror, 1996) и зато што могу да утичу на психологе да поштују или да крше професионалну етику (Петровић, 2016). У нашој средини, у највећем броју случајева, практичари ППС су психолози, најчешће ठез додатне формалне едукације и тренинга. Други циљ овог рада је приказивање резултата експлоративног истраживања (пилот студије) - у коме смо испитали уверења студената психологије (будућих психолога) о етици понашања спортских психолога.

\section{НАЈЧЕШЋА ЕТИЧКА ПИТАҢА У ПРИМЕЊЕНОЈ ПСИХОЛОГИЈИ СПОРТА}

Постављање граница. У оквиру саветодавног и психотерапијског односа постављају се јасне границе са циљем дефинисања улоге сваке од страна у односу и да се заштити добробит клијената (Speight, 2012). У последње две деценије, у литератури се појављује став да сваки прелазак граница не представља њихово кршење и не мора бити штетан по клијента (Barnett, Lazarus, Vasquez, Moorehead-Slaughter, \& Johnson, 2007). 
Консултације које обављају спортски психолози по својој природи могу да представљају прелазак граница (Moles, Petrie, \& Watkins, 2016). Заправо, када спортски психолози разматрају примереност свога понашања треба да га сагледају кроз призму спортског окружења (Speight, 2012). Поред обављања праксе на традиционалним местима у саветовалиштима у оквиру приватне праксе или универзитета, уобичајено је да спортски психолог обавља консултације са спортистима и са тренерима и изван класичног психотерапијског сетинга, нпр. у просторији за припрему пред такмичарски наступ, свлачионици, током путовања (у аутобусу, авиону), у хотелу (Andersen, Van Raatle, \& Brewer, 2001; Brown, \& Cogan, 1994; Etzel \& Watson 2007; Moore, 2003; Stapleton, et al., 2010; Haberl, \& Peterson, 2006). Ово се посебно односи на оне психологе који раде са спортским тимовима или у оквиру спортских организација (Moore, 2003). Неретко, распореди спортиста који су унапред испланирани и окупирају спортисту читавог дана, не омогућавају да сеансе трају како је уобичајено 45-60 минута, већ има времена само за кратке интервенције које се некада обављају и током обедовања (Stapleton, et al., 2010). Оваква пракса омогућава да психолог помогне спортисти да функционише што је могуће оптималније, како би остварио своје личне циљеве и циљеве тима и/ или спортске организације (Moore, 2003). Спортисти могу да се осећају лагодније када је психолог са њима и када консултације могу да се одвијају када су им потребне (на пример, непосредно пред такмичарски наступ, након пораза). Следећа предност оваквог начина рада је у постојању више могућности да психолог боље упозна и тренера и спортисту, као и да присуствује њиховим реакцијама у кризним ситуацијама. Јасно је да су у описаном окружењу, границе мање ригидне него у клиничкој пракси. Додатно, етичке дилеме могу да се појаве у оним ситуацијама у којима је више социјалне интеракције (АРА, 2002). На пример, психолога могу позвати да присуствује прослави након победе тима или га тренери могу позвати да попију пиће у бару. Како психолог треба да поступи ако се нађе у таквој ситуацији? Ако одбије да дође, то може направити дистанцу у односу (а блискост у односу психолог-спортиста има кључни значај). Обично је потребан дужи временски период да психолог са спортистима и са осталим званичницима (ако ради у оквиру одређене спортске организације) развије добар радни савез и оствари блискост, те да и на даље буде поштована, цењена и особа од поверења (Moore, 2003). Са друге стране, не треба занемарити и други могући сценарио: спортисти који су долазили код психолога у циљу решавања конкретних проблема и који су са психологом изградили добар радни савез после завршетка третмана затраже помоћ у будућности. Ако психолог прихвати да присуствује таквим догађајима, неопходно је да све време буде свестан професионалних граница, да се „чува“ од блиских интеракција, те да води површне разговоре. У литератури се наводи искуство психолога који је често био позиван да присуствује таквим социјалним догађајима. Он се наметнуо у улози возача у ситуацијама у којима се конзумирао алкохол, што му је омогућило да буде укључен у догађај, али и да задржи професионали однос и да очува границе (Brown, \& Cogan, 1994). Још једна карактеристична ситуација, која може бити етички упитна, тиче се места обављања консултација са спортистима током путовања. Замислимо честу ситуацију да у хотелу није доступна посебна просторија за обављање консултација. Обављање консултација са спортистима у лобију хотела може да доведе до кршења начела поверљивости. Исто тако, психолог може са појединачним спортистима или са групом спортиста да обавља консултације у хотелској соби (Moore, 2003) што може да отвори питање потенцијалних сексуалних намера (неки психолози разрешавају ову ситуацију „радећи са отвореним вратима“). Закључно, психолог не мора по сваку цену да избегава овакве ситуације, већ да у тим ситуацијама себе представља на професионални начин и да свима буде јасна његова улога и начин на који је он укључен (Moore, 2003).

Поверљивост. Добар однос између професионалца, било да је он психолог, психотерапеут, консултант, супервизор, спортски психолог и клијента (то може бити индивидуални спортиста, спортски тим, тренер и остали званичници клуба, родитељи спортисте) представља кључну компоненту за успешан исход (Stapleton, et al., 2010). Основу овог односа чини поверење. Чак и најмање кршење начела поверљивости може негативно да се одрази на њихов однос. Најчешће трећа страна - родитељи спортисте, тренер или други званичници клуба могу упутити спортисту 
код психолога и са њиме остварити први контакт. Није ретко да трећа страна претпоставља да аутоматски полаже право на информације о осетљивим подацима везаним за третман и напредовање (Moore, 2003). Додатна компликација може да настане уколико трећа страна финансира третман. Ово је честа ситуација са родитељима који су у високом степену укључени у спортску активност своје деце. Може се догодити да психолог паралелно ради и са спортистом и са његовим родитељима. Веома је важно да развије посебну осетљивост за додатна питања и за одржавање поверљивости. У таквим случајевима питања поверљивости су знатно сложенија и захтевају додатну опрезност и балансирање. Једно од најосетљивијих питања јесте у ком степену сваки члан породице рачуна на поверљивост у оквиру породице, што је посебно изражено ако чланови породице долазе и појединачно. Могуће су грешке у два смера. Ако психолог даје обиље информација (при чему не мора да крши начело поверљивости) може изгледати као да је начело поверљивости нарушено. Супротно томе, ако психолог пружа исувише мало информација може да створи сумњу у вези са самим процесом. У таквим ситуацијама психолог ће најбоље поступити ако охрабрује чланове породице да размењују информације када сматрају да је то прикладно. Када постоји сумња у ту могућност, психолог може да упита сваког члана породице који би део информација било прикладно да подели са осталим члановима породице.

Када спортски психолог ради са професионалним спортским организацијама, не може да претпостави исте границе поверљивости, као када ради са појединачним спортистом (Gardner, 2001). У том процесу треба имати у виду и циљеве спортисте и циљеве спортске организације, ако је она ангажовала психолога (у том случају и организација је клијент). Тренери, званичници клуба, па чак и медији могу сматрати да поседују право на ове привилеговане информације. На пример, замислимо да спортски клуб (трећа страна у односу) ангажује психолога да процени карактеристике личности спортиста и да је задатак психолога да спортском клубу сачини извештаје. Неопходно је да спортиста о томе буде информисан. Зато већ у току првог контакта са трећом страном психолог треба да постави јасне границе поверљивости информација у односу са спортистом (Moore, 2003). Уколико, на пример, трећа страна од психолога затражи информације о спортисти, он би требало да је упути на спортисту. Будући да однос између психолога и треће стране може да утиче на квалитет и трајање односа психолог спортиста, зато и између њих треба да се развије однос поверења. Један од првих корака је подстицање треће стране да подржи третман спортисте, што подразумева поштовање поверљивости. Уколико је консултант по свом образовању психолог, може се десити да са спортистом ради и на проблемима који превазилазе спортско напредовање, па чак и рад са проблемима из области клиничке психологије (поремећаји исхране, анксиозност, депресија итд.). У неким случајевима тренер може имати активно учешће у третману. У том случају неопходно је од спортисте тражити писану сагласност о могућностима откривања информација (и у ком степену се оне могу дати трећој страни). Често тренери који су информисани о границама поверљивости, консултанту постављају питања о напредовању спортисте. На пример, ако је спортиста напредовао тренер жели да зна о чему је спортиста разговарао са психологом, највероватније како би и сам знао како може да подржи спортисту у будућим ситуацијама. Ове ситуације су учесталије уколико се психолог и тренер лично познају. Тада психолог може да пита спортисту о чему и колико информација може да саопшти тренеру. Ова ситуација, нелагодна за све укључене стране, може се предупредити тако што ће се овај договор поставити унапред, а комуникација консултанта са трећом страном унапред испланирати. Кодексом Америчке психолошке асоцијације је предвиђено да психолог може да даје информације трећој страни, али само оне, које се директно тичу постизања одређеног циља (професионалног или научног) и само одређеној особи. Остале информације, које нису директно повезане са циљем третмана, не смеју се откривати (APA, 2002).

Обављање консултација на јавним местима, током тренинга или током такмичења, је још један важан аспект праксе за који психолог треба да развије посебну осетљивост (Huang, \& Hung, 2008). Спортисти не морају да обрате пажњу на то ко се налази у близини, али психолог је дужан да опрезно разговара о поверљивим информацијама које друге особе могу да чују. Андерсен и сарадници (2001) дају две сугестије у вези са оваквим ситуацијама. Једна је да психолог и спортиста 
покушају да пронађу неко звучно изоловану просторију, а друга је да консултацију о поверљивим питањима закажу у друго време.

Компетентност. Психологија спорта је специјализован домен и захтева специјализовану компетентност (Brown, \& Cogan, 1994). Погрешно је веровање да се компетентност за психологију спорта може стећи великим интересовањем за теме из психологије спорта, читањем литературе или пак да бивши успешни спортисти или тренери поседују ову компетентност. Психолози могу бити компетентни за саветовање или психотерапију, али да би били компетентни за област психологије спорта, неопходно је да стекну специфична знања из спортских наука и из медицине спорта, као и да се континуирано усавршавају (Stapleton et al., 2010). Такође је важно да поседују одређене компетенце у оквиру суб-специјалности. Тако на пример, практичари уочавају значајне разлике у раду са спортистима који су различитог такмичарског ранга (Stapleton et al., 2010). Једнако је значајно да уваже специфичне аспекте када раде са младим спортистима, са универзитетским спортистима, у оквиру спортских организација или са професионалним и врхунским спортистима, као и особености сваке спортске гране. Након завршених формалних програма који обухватају знања из психологије спорта, а у циљу заштите добробити клијента, значајно је да психолог иде на супервизију која може да варира од учестале до годишње, код супервизора - експерта за област и код вршњачког супервизора (Barney, Andersen, \& Riggs, 1996). У релевантној литератури (Brown, \& Cogan, 1994; Moore, 2003; Stapleton et al., 2010) je постигнута сагласност да психолози могу да прекораче границе своје компететности на два начина. Један је кад је психолог ангажован за рад са спортистом у циљу унапређивања такмичарског извођења, а током рада открије постојање психопатолошког проблема (нпр. поремећај исхране, поремећај расположења). Ако није обучен за примену третмана таквог проблема, и уколико не упути спортисту код колеге који је специјалиста у тој области, обавља праксу која је изван његове компетентности. Други се огледа у томе да психолог са спортистом који жели да унапреди своје такмичарско извођење изгради саветодавни / психотерапијски однос, а да није компетентан за рад на унапређивању спортског извођења, тј. да није овладао менталним тренингом за спортисте. Такође, примена мерних инструмената за које психолог није квалификован, представља превазилажење граница компетентности (Moore, 2003).

\section{УВЕРЕЊА СТУДЕНАТА ПСИХО- ЛОГИЈЕ О ЕТИЦИ ПОНАШАЬА СПОРТСКИХ ПСИХОЛОГА}

\section{Узорак и поступак мерења}

У истраживању је учествовало 92 студената психологије, Филозофског факултета Универзитета у Београду, од чега је $75(81,52 \%)$ женског, а 17 (18,48\%) мушког пола. Просечна старост испитаника је 22,08 година $(\mathrm{SD}=1,59)$ Већина студената је на трећој години студија 79 (85,87\%), а мањи број на четвртој 13 (14,13\%). Проценат одбијања учествовања у истраживању био је занемарљив $(10,6 \%)$ и несистематски. Испитивање је било анонимно, а упитници су примењивани преко платформе SurveyMonkey.

\section{Инструмент}

Упитник садржи 9 ставки којима се описују хипотетичка понашања спортског психолога, а испитаници треба да процене етичност тих поступака на петостепеној скали Ликертовог типа (од 1 = апсолутно неетично до 5 = етично без сумње) тако што би навели у којој мери се слажу да је одређено поступање етично. Тврдње у ставкама срочене су у трећем лицу, нпр. „Откривање поверљивих података о спортисти тренеру.“ Као извори коришћени за одређивање садржаја ставки упитника послужила су теоријска знања и практична искуства аутора.

\section{РЕЗУЛТАТИ}

Већина ставки у упитнику описује комплексна етичка питања. Добијени резултати (f и \%) су приказани у Табели 1. Понашања психолога која се односе на прихватање позива психолога за одлазак на утакмицу, на прославу, упуштање у сексуални или романтични однос са клијентом, односе се на начело поштовања граница. Резултати овог истраживања показују да две трећине испитаника сматра да је упуштање у романтични однос са бившим клијентом без сумње неетично, односно 
етично у ретким ситуацијама. Још већа сагласност постоји (готово сви испитаници) око упуштања у сексуални однос са садашњим клијентом, које је етичким кодексом стриктно забрањено. Ово понашање студенти процењују као ठез сумње неетично. Међутим, око 70\% студената сматра да је присуствовање прослави тима након победе без сумње неетично и етично у ретким ситуацијама. Уколико се има у виду да спортски психолози не ретко консултације обављају на нетрадиционалним местима, укључујући и такмичења, податак који забрињава јесте да скоро половина студената (47\%) сматра да је прихватање позива за одлазак на такмичење неетично. Тек нешто мање од 10\% испитаника сматра да је ово понашање, које је карактеристично за спортске психологе, без сумње етично. Занимљиви подаци су добијени о начелу поверљивости - откривању података родитељима, тренеру и власнику клуба, као и о позитив- ним сведочењима спортиста о раду психолога као виду рекламе. Нешто више од половине испитаника сматра да је рекламирање путем позитивних сведочења спортиста о раду психолога неетично без сумње. Око петине испитаника сматра да је откривање података о малолетном клијенту његовим родитељима без сумње неетично. Знатно већи проценат, (близу 60\%) сматра да је откривање података власнику тима без сумње неетично, а највећи консензус (91\%) постигнут је око тога да је откривање података о спортисти његовом тренеру без сумње неетично. Ниједан испитаник није се определио за одговор да је откривање података тренеру етично у већини ситуација и без сумње етично понашање. Када је у питању компетентност, релативно висок проценат испитаних студената (85\%) сматра да саветовање у вези са проблемом, за који психолог није компетентан, припада категорији неетичног понашања.

Табела 1. Фреквенце и проценти одговора испитаника за сваку категорију питања у упитнику

\begin{tabular}{|c|c|c|c|c|c|}
\hline \multirow[t]{2}{*}{ Ставке из упитника } & $\begin{array}{l}\text { Без сумње } \\
\text { неетично } \\
\text { понашање }\end{array}$ & $\begin{array}{c}\text { Етично } \\
\text { понашање } \\
\text { у ретким } \\
\text { ситуацијама }\end{array}$ & $\begin{array}{l}\text { Понашање } \\
\text { које је } \\
\text { понекад } \\
\text { етично }\end{array}$ & $\begin{array}{c}\text { Етично } \\
\text { понашање } \\
\text { у већини } \\
\text { ситуација }\end{array}$ & $\begin{array}{l}\text { Без сумње } \\
\text { етично } \\
\text { понашање }\end{array}$ \\
\hline & $\mathbf{f}(\%)$ & $\mathbf{f}(\%)$ & $\mathbf{f}(\%)$ & $\mathbf{f}(\%)$ & $\mathbf{f}(\%)$ \\
\hline $\begin{array}{l}\text { Слављење са тимом у кафани после } \\
\text { победе }\end{array}$ & $35(46,1)$ & $18(23,7)$ & $13(17,1)$ & $7(9,2)$ & $3(3,9)$ \\
\hline $\begin{array}{l}\text { Прихватање позива од клијента за } \\
\text { такмичење или утакмицу }\end{array}$ & $15(19,7)$ & $21(27,6)$ & $16(21,1)$ & $17(22,4)$ & $7(9,2)$ \\
\hline $\begin{array}{l}\text { Упуштање у романтични однос са бившим } \\
\text { клијентом }\end{array}$ & $38(50,0)$ & $14(18,4)$ & $14(18,4)$ & $4(5,3)$ & $6(7,9)$ \\
\hline Упуштање у сексуални однос са клијентом & $74(97,4)$ & $1(1,3)$ & $1(1,3)$ & / & / \\
\hline $\begin{array}{l}\text { Укључивање позитивних „сведочења“ } \\
\text { спортиста о успеху рада психолога у } \\
\text { рекламу }\end{array}$ & $39(51,3)$ & $26(34,2)$ & $7(9,2)$ & $4(5,3)$ & / \\
\hline $\begin{array}{l}\text { Откривање поверљивих података } \\
\text { о малолетном клијенту његовим } \\
\text { родитељима }\end{array}$ & $16(21,1)$ & $33(43,4)$ & $15(19,7)$ & $8(10,5)$ & $4(5,3)$ \\
\hline $\begin{array}{l}\text { Откривање поверљивих података о } \\
\text { клијенту тренеру }\end{array}$ & $69(90,8)$ & $5(6,6)$ & $2(2,6)$ & / & / \\
\hline $\begin{array}{l}\text { Откривање података о напредовању у } \\
\text { раду са клијентом власнику тима }\end{array}$ & $45(59,2)$ & $15(19,7)$ & $10(13,2)$ & $4(5,3)$ & $2(2,6)$ \\
\hline $\begin{array}{l}\text { Саветовање клијента у вези са проблемом } \\
\text { за који психолог није компетентан да } \\
\text { решава }\end{array}$ & $34(44,7)$ & $31(40,8)$ & $7(9,2)$ & $2(2,6)$ & $2(2,6)$ \\
\hline
\end{tabular}




\section{ДИСКУСИЈА}

За остваривање професионалних циљева у оквиру ППС значајно је да се психолози интегришу у спортску средину и да своју праксу прилагоде захтевима спортске културе. У таквом окружењу од психолога се захтева спонтаност, флексибилност и могућност да одговори на променљиве потребе клијената. Они се сусрећу са етичким дилемама које су атипичне за стандардну психотерапијску праксу, а најчешће се односе на питања очувања граница у средини која се за праксу психолога не сматра традиционалном, на питања поверљивости и питања компетентности (Brown, \& Cogan, 1994; Moore, 2003). Са друге стране, подразумева се да се психолози придржавају етичког кодекса, те да је неопходно да стекну специфично етичко образовање које утиче на то како ће они поступати са етичким изазовима. Развој специфичне осетљивости за етичка питања је посебно значајна за психологе који раде у оквиру спортских организација (Gardner 2001). Имајући у виду да је последњих година у нашој средини све већи број психолога који се ангажују у овом пољу, те да код нас нема формалног етичког образовања за ову област нити су кодексом ДПС-а истакнуте специфичности етике спортских психолога, први циљ овога рада био је да се представе карактеристичне етичке дилеме и могуће ситуације у којима оне могу да настану. Други циљ био је да се емпиријски испита како студенти психологије - будући стручњаци од којих ће се неки можда определити за рад у оквиру ППС - процењују етичност понашања спортских психолога у одређеним ситуацијама.

У контексту у коме се обавља ППС, границе су мање ригидне у поређењу са границама класичне психотерапијске праксе (Andersen et al., 2001; Brown, \& Cogan, 1994; Etzel \& Watson 2007; Haberl, \& Peterson, 2006; Moore, 2003; Stapleton et al., 2010). За разлику од бројних истраживања у вези са границама у психотерапијском и саветодавном односу, готово да нема истраживања посвећених истим питањима у односу спортски психолог - спортиста са којима можемо да упоредимо резултате нашег истраживања. Скоро половина испитаника сматра да је одлазак психолога на спортско такмичење неетично и још већи проценат (око 70\%) дели мишљење о присуствовању психолога социјалним догађајима. Наши резул- тати имају подршку у истраживању Петитпаса и сарадника (1994), према којима преко 40\% испитаника - практичара ППС регистрованих у Удружењу за унапређивање примењене психологије спорта у САД сматра да је присуствовање социјалним догађајима без сумње неетично, а нешто мање од $25 \%$ сматра да је етично у ретким ситуацијама. Међутим, резултати истраживања Молеса и сарадника (2016) нису у складу са резултатима нашег истраживања. Према резултатима тог истраживања, чак преко 90\% испитаника сматра да присуствовање такмичењима и посебним догађајима и малим друштвеним окупљањима, припада категорији понашања која су у највећем степену професионална. Када упоређујемо разлике у добијеним резултатима треба да имамо у виду да су испитаници у нашем истраживању били студенти завршних година студија, те да они нису похађали специфичне курсеве из етике спортске психологије, док су у истраживању Молеса и сар. испитаници сертификовани практичари ППС (укључујући и психологе или стручњаке из наука о спорту). Заправо, ова понашања могу бити неопходна за ефикасно и професионално обављање праксе спортских психолога (Haberl, \& Peterson, 2006) и очигледно је да се и став америчких психолога временом променио. Испитаници из овог истраживања сматрају да је упуштање у сексуални однос са бившим клијентом ठез сумње неетично што је у сагласности са резултатима Петитпаса и сарадника (1994). Ови истраживачи су известили да преко 92.7\% испитаника ово понашање сматра увек неетичким.

Поверљивост у односу психолог - спортиста сматра се каменом темељцем ефикасне праксе (Moore, 2003). Обично је потребно дуже време да психолог са клијентима оствари добар радни савез, блискост и однос поверења. Управо зато се препоручује да психолог прихвати да део своје праксе обавља „на терену“, онда када је спортистима најпотребније. У литератури се истиче да присуствовање различитим социјалним догађајима не мора да буде штетно за напредовање клијента нити за њихов однос. У таквим околностима од есенцијалне важности је да психолог све време буде свестан свог понашања и да задржи професионалне границе у односу (Brown, \& Cogan, 1994). Испуњавајући потребе тима као и појединачних спортиста у тиму, пред психолога се постављају захтеви у вези са поштовањем начела поверљиво- 
сти (Stapleton et al., 2010). Уколико психолог ради са малолетним спортистима чији су родитељи заинтересовани за детаље напредовања и тока третмана, психолог је дужан да заштити поверене информације. У том процесу један од кључних корака јесте да психолог трећу страну у односу (родитеља, тренера, званичника клуба) подржи да поштује начело поверљивости и да их већ у току првог контакта обавести о томе (Moore 2003). У нашем истраживању добијени су донекле неочекивани резултати. Наиме, постоји релативно висока сагласност испитаника да је откривање поверљивих података о спортисти трећој страни неетично понашање. Добијени одговори су у складу са кодексима у којима је предвиђено да психолог може трећој страни да даје само оне информације које се тичу постизања одређеног професионалног циља (АПА, 2002, ДПС, 2000). Међутим, док приближно $80 \%$ испитаника процењује да је откривање података родитељима спортисте некада етично, а око $40 \%$ исто мисли за откривање информација власнику тима, парадоксално мање од $10 \%$ испитаника сматра да је откривање података тренеру (који је једини у улози инструктора, ментора, демонстратора, стручног саветника) припада категорији етичног понашања у неким ситуацијама. У недостатку емпиријских података за тумачење добијених резултата, можемо изнети претпоставку да је управо специфична улога и одговорност коју има тренер код наших испитаника довео до неповерљивости и бојазни од могуће ненамерне злоупотребе података.

Рад са проблемима за које психолог није оспособљен коси се са начелом компетентности. Остваривање компетентности у оквиру ППС захтева поседовање специјализованих знања и вештина (Brown, \& Cogan, 1994) која представљају интеграцију различитих области психологије, спортске медицине и наука о спорту. За ефикасну праксу, неопходно је да психолог познаје специфичности сваке спортске гране, такмичарски ниво, као и карактеристике сваког спортисте. Разноврсност питања и проблема са којима се практичари сусрећу, довела је до развоја одрећених суб-специјалности (Stapleton, Hanks, Hayes \& Parham, 2010). Након завршене формалне едукације, континуирано усавршавање и различити облици супервизије могу значајно да доприносу даљем развоју и одржавању компетентности (Barney et al., 1996). У нашем истраживању око
85\% испитаника проценило је да саветовање клијента за проблем за који психолог није компетентан припада категоријама неетичког понашања (без сумње и у ретким ситуацијама). Сагласни истраживачки налази су добијени у истраживању Петитпаса и сарадника (1994) према којима око 87\% испитаника сматра да је рад са проблемима за које психолог нема формални тренинг неетично, а истовремено око 73\% испитаника сматра да је саветовање спортисте без едукације из области саветовања и/или психотерапије неетично или ретко етично понашање.

У пракси спортски тренери, било да мање или више активно сарађују са спортским психологом, својим ангажовањем и захтевима које постављају спортистима и психолозима могу да утичу на учесталост јављања етичких дилема. Посматрано из тог угла, било би значајно испитати мишљења студената физичког васпитања и спорта о томе колико су понашања спортских психолога етична или неетична. Добијени резултати би ठили полазна основа за креирање програма етичке едукације будућих спортских тренера (а не само психолога), а резултати овог истраживања би добили више етичке валидности.

\section{ЗАКЉУЧАК}

За професионално и ефикасно обављање сложене праксе ППС нужно је да психолог у потпуности разуме своју професионалну улогу и да у складу са специфичним захтевима и потребама јединствене „клијентеле“ своју праксу асимилује у спортску културу. Упоредо са растућим интересовањем и све већом популарношћу ове интердисциплинарне области, отварају се бројна питања око тога како пружити најбоље могуће услуге поштујући етику. Једно од најновијих је и рад са спортистима преко интернета, нпр. путем скајпа, с обзиром да спортисти често путују у иностранство на такмичења, а да их психолози не могу увек пратити. Како у нашој средини ППС још увек стиче свој углед, може се догодити да неефикасна пракса не дискредитује само психолога већ и професију. Поред тога, ови први емпиријски подаци о етичким уверењима у вези са понашањем спортских психолога указују на потребу за развојем специфичних програма тренинга из етике ППС у нашој средини. Полазна тачка и узор за развој 
оваквих програма могу бити програми тренинга и искуства спортских психолога из држава у којима су такви програми већ развијени.

\section{ЛИТЕРАТУРА}

1. Anderesen, M. B., Van Raatle, J. L., \& Brewer, B. W. (2001). Sport Psychology Service Delivery: Staying Ethical While Keeping Loose. Professional Psychology: Research and Practice, 32, 12-18.

2. American Psychological Association. (2002). Ethical principles of psychologists and code of conduct. American Psychologist, 57, 1060-1073.

3. Barnett, J. E., Lazarus, A. A., Vasquez, M. J. T., Moorehead-Slaughter, O., \& Johnson, W. B. (2007). Boundary issues and multiple relationships: Fantasy and reality. Professional Psychology: Research and Practice, 38, 401-410.

4. Barney, S. T., Andersen, M. B., \& Riggs, C. A. (1996). Supervision in sport psychology: Some recommendations for practicum training. Journal of applied sport psychology, 8, 200-217.

5. Brown, J. L., \& Cogan, K. D. (2006). Ethical clinical practice and sport psychology: When two worlds collide. Ethics \& behavior, 16, 15-23.

6. Društvo psihologa Srbije (2000). Kodeks etike psihologa Srbije. Beograd: Društvo psihologa Srbije.

7. Etzel, E., \& Watson, J. (2007) Ethical challenges for psychological consultations in intercollegiate athletics. Journal of Clinical Sport Psychology, 1, 304-317.

8. Gardner, F. L. (2001). Applied sport psychology in professional sports: The team psychologist. Professional Psychology: Research and Practice, 32, 34-39.

9. Lavallee, D., Kremer, J., Moran, A.P., \& Williams, M. (2004). Sport Psychology: Contemporary Themes. New York: Palgrave Macmmillan.

10. Haberl, P., \& Peterson, K. (2006). Olympic-size ethical dilemas: Issues and challenges for sport psychology consultants on the road and Olympic Games. Ethics \& Behavior, 16, 25-40.

11. Huang, C. J., \& Hung, T. M. (2008). Ethical issues in sport psychology services: Dual relationships, confidentiality, and competence boundaries. Bulletin of Sport and Exercise Psychology of Taiwan, 13, 53-69.

12. Moles, T. A., Petrie, T. A., \& Watkins, C. E. (2016). Sex and Sport: Attractions and Boundary Cross-
Напомене: Рад је резултат реализације задатака Пројекта (III47015; No 47008) који подржава Министарство просвете, науке и технолошког развоја Србије.

ings Between Sport Psychology Consultants and Their Client-Athletes. Professional Psychology: Research and Practice, 47, 93-101.

13. Moore, Z.E. (2003). Ethical Dilemmas in Sport Psychology: Discussion and Recommendations for Practice. Professional Psychology: Research and Practice, 34, 601-610.

14. Petitpas, A. J., Brewer, B. W., Rivera, P. M., \& Van Raalte, J. L. (1994). Ethical beliefs and behaviors in applied sport psychology: The AAASP ethics survey. Journal of Applied Sport Psychology, 6, 135-151.

15. Pack-Brown, S. P., \& Williams, C. B. (2003). Ethics in a multicultural context. London: Sage Publications, Inc.

16. Petrović, M.N. (2016). Efekat etičke pozicije i edukacije na etička uverenja psihologa koji se bave psihoterapijom u Srbiji. Primenjena psihologija, 9, 261-272.

17. Pope, K. S., Tabachnick, B. G., \& Keith-Spiegel, P. (1987). Ethics of practice: The beliefs and behaviours of psychologists as therapists. American Psychologist, 42, 993-1006.

18. Rubin, S., \& Dror, O. (1996). Professional ethics of psychologists and physicians: Mortality, confidentiality, and sexuality in Israel. Ethics and Behavior, 6, 213-238.

19. Speight, S. (2012). An exploration of boundaries and solidarity in counseling relationships. The Counseling Psychologist, 40, 133-157.

20. Stapleton, A., Hanks, D., Hayes, K., \& Parham, W. (2010). Ethical dilemmas in sport psychology: A dialogue on the unique aspects impacting practice. Professional Psychology: Research and Practice, 41, 143-152.

21. Wylleman, P., Harwood, C. G., Elbe, A.-M., \& de Caluwé, D. (2009). A perspective on education and professional development in applied sport psychology. Psychology of Sport and Exercise, 10, 435-446.

22. Weinberg, R., \& Gould, D. (2011). Foundations of Sport and Exercise Psychology (5h Ed.). Champaign, Illinois: Human Kinetics. 


\section{ETHISCHE BILDUNG IN ANGEWANDTER SPORTPSYCHOLOGIE}

\section{Zusammenfassung}

In der angewandten Sportpsychologie wird von Psychologen oft erwartet, ihre Arbeit außerhalb des Rahmnes der traditionellen klinischen Praxis zu machen, was Vorteile, aber auch Begrenzungen hat. Praktiker sind oft mit spezifischen Dilemmas konfrontiert und können nicht alle Antworten im Ethikkodex finden. Empirisch wurde dokumentiert, dass ethische Bildung ein wichtiges Instrument im Kampf gegen den Bruch von ethischen Prinzipien darstellt. Sie bekommt an Kraft, unter anderem auch wegen der Tatsache, dass in den letzten Jahren die Anzahl von Psychologen in diesem Bereich angestiegen ist. Aus diesem Grunde befindet sich der Schwerpunkt dieser Arbeit auf dem ersten Ziel - der Beschreibung des Spezifikums der Ethik in der angewandten Sportpsychologie. Auf Grund einer Revision von relevanter Literatur wurden die drei häufigsten Fragen ausgesondert: die Festlegung von Grenzen, Vetraulichkeit und Kompetenz. Im zweiten, kleineren empirischen Teil wurden Ergebnisse einer Pilotstudie über ethische Überzeugungen in Bezug auf das Verhalten von Sportpsychologen vorgestellt. Die Informationen wurden an einem Muster von Psychologiestudenten (N=92) gesichert, von denen manche vielleicht den Beruf des Sportpsychologen aussuchen werden. Manche der Verhaltensweisen, die für effiziente praktische Arbeit unumgänglich, aber untypisch für die traditionelle klinische Praxis sind (z.B. Anwesenheit eines Psychologen bei einem Wettbewerb) wurden fast von der Hälfte der Prüflinge als unethisch eingeschätzt. Die größte Übereinstimmung der Prüflinge wurde bei der Frage über die Enthüllung von vetraulichen Informationen dem Trainer gegenüber erzielt. Auf Grund dieser Arbeit wurde eine Empfehlung formuliert, die sich auf das Bedürfnis nach Entwicklung von spezifischen Trainingsprogramms für Ethik in angewandter Sportpsychologie bezieht.

Schlüsselwörter: KLINISCHE SPORTPSYCHOLOGIE / ETHISCHE DILEMMAS / GRENZEN / VETRAULICHKEIT / KOMPETENZ

Примљен: 09.11.2017.

Прихваћен: 05.12. 2017. 